Soldiers, Citizens and Civilians 
Series Editors: Rafe Blaufarb (Tallahassee, USA), Alan Forrest (York, UK), and Karen Hagemann (Chapel Hill, USA)

Editorial Board: Michael Broers (Oxford, UK), Christopher Bayly (Cambridge, UK), Richard Bessel (York, UK), Sarah Chambers (Minneapolis, USA), Laurent Dubois (Durham, USA), Etienne François (Berlin, Germany), Janet Hartley (London, UK), Wayne Lee (Chapel Hill, USA), Jane Rendall (York, UK), Reinhard Stauber (Klagenfurt, Austria)

Titles include:

Alan Forrest and Peter H. Wilson (editors)

THE BEE AND THE EAGLE

Napoleonic France and the End of the Holy Roman Empire, 1806

Alan Forrest, Karen Hagemann and Jane Rendall (editors)

SOLDIERS, CITIZENS AND CIVILIANS

Experiences and Perceptions of the Revolutionary and Napoleonic Wars, $1790-1820$

\section{Forthcoming:}

Karen Hagemann, Gisela Mettele and Jane Rendall (editors) GENDER, WAR AND POLITICS

The Wars of Revolution and Liberation - Transatlantic Comparisons, 1775-1820

Alan Forrest, Etienne François and Karen Hagemann (editors) WAR MEMORIES

The Revolutionary and Napoleonic Wars in Nineteenth and Twentieth Century Europe

Richard Bessel, Nicholas Guyatt and Jane Rendall (editors)

WAR, EMPIRE AND SLAVERY, 1770-1830

\section{War, Culture and Society, 1750-1850}

\section{Series Standing Order ISBN 978-0-230-54532-8 hardback}

978-0-230-54533-5 paperback

(outside North America only)

You can receive future titles in this series as they are published by placing a standing order. Please contact your bookseller or, in case of difficulty, write to us at the address below with your name and address, the title of the series and the ISBN quoted above.

Customer Services Department, Macmillan Distribution Ltd, Houndmills, Basingstoke, Hampshire RG21 6XS, England 


\section{Soldiers, Citizens and Civilians}

Experiences and Perceptions of the Revolutionary and Napoleonic Wars, 1790-1820

Edited by

Alan Forrest

Professor of Modern History, University of York

Karen Hagemann

James G. Kenan Distinguished Professor of History,

University of North Carolina at Chapel Hill, USA

and

Jane Rendall

Honorary Fellow, Centre for Eighteenth Century Studies, University of York

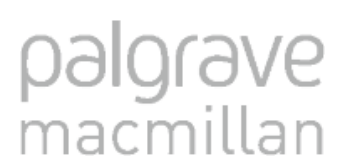




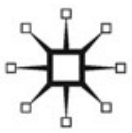

Editorial matter, selection, foreword, introduction @ Alan Forrest, Karen Hagemann and Jane Rendall 2009.

All remaining chapters @ their respective authors 2009.

Softcover reprint of the hardcover 1st edition 2009 978-0-230-54534-2

All rights reserved. No reproduction, copy or transmission of this publication may be made without written permission.

No portion of this publication may be reproduced, copied or transmitted save with written permission or in accordance with the provisions of the Copyright, Designs and Patents Act 1988, or under the terms of any licence permitting limited copying issued by the Copyright Licensing Agency, Saffron House, 6-10 Kirby Street, London EC1N 8TS.

Any person who does any unauthorized act in relation to this publication may be liable to criminal prosecution and civil claims for damages.

The authors have asserted their rights to be identified as the authors of this work in accordance with the Copyright, Designs and Patents Act 1988.

First published 2009 by PALGRAVE MACMILLAN

Palgrave Macmillan in the UK is an imprint of Macmillan Publishers Limited, registered in England, company number 785998, of Houndmills, Basingstoke, Hampshire RG21 6XS.

Palgrave Macmillan in the US is a division of St Martin's Press LLC, 175 Fifth Avenue, New York, NY 10010.

Palgrave Macmillan is the global academic imprint of the above companies and has companies and representatives throughout the world.

Palgrave ${ }^{\circledR}$ and Macmillan ${ }^{\circledR}$ are registered trademarks in the United States, the United Kingdom, Europe and other countries.

ISBN 978-1-349-36086-4

DOI $10.1057 / 9780230583290$

ISBN 978-0-230-58329-0 (eBook)

This book is printed on paper suitable for recycling and made from fully managed and sustained forest sources. Logging, pulping and manufacturing processes are expected to conform to the environmental regulations of the country of origin.

A catalogue record for this book is available from the British Library.

A catalog record for this book is available from the Library of Congress.

$\begin{array}{llllllllll}10 & 9 & 8 & 7 & 6 & 5 & 4 & 3 & 2 & 1\end{array}$

$\begin{array}{llllllllll}18 & 17 & 16 & 15 & 14 & 13 & 12 & 11 & 10 & 09\end{array}$ 


\section{Contents}

Foreword to the Series

Acknowledgements

Notes on Contributors

$\mathrm{X}$

Introduction: Nations in Arms - People at War

Alan Forrest, Karen Hagemann and Jane Rendall

\section{Part I Military Experiences}

1 Regimental Worlds: Interpreting the Experience of British Soldiers during the Napoleonic Wars John E. Cookson

2 Survivors of War: French Soldiers and Veterans of the Napoleonic Armies

Natalie Petiteau

3 Glory, Honour and Patriotism: Military Careers in the Duchy of Warsaw, 1806-1815

Jarostaw Czubaty

4 The World Turned Upside Down: Female Soldiers in the French Armies of the Revolutionary and Napoleonic Wars David Hopkin

\section{Part II Civilians at War}

5 Caring for the Nation's Families: British Soldiers' and Sailors' Families and the State, 1793-1815

Patricia Y. C. E. Lin

6 War without Battles: Civilian Experiences of Economic

Warfare during the Napoleonic Era in Hamburg

Katherine B. Aaslestad 
7 From the Ballroom to the Battlefield: British Women and Waterloo

Catriona Kennedy

8 'Unimaginable Horror and Misery': The Battle of Leipzig in October 1813 in Civilian Experience and Perception

Karen Hagemann

\section{Part III War, Patriotism and Protest}

9 'A Very Rebellious Disposition': Dutch Experience and Popular Protest under the Napoleonic Regime (1806-1813) Johan Joor

10 'A Citizen and Not a Soldier': The British Volunteer Movement and the War against Napoleon Kevin B. Linch

11 Religion and the Experience of War: A Comparative Approach to Belgium, the Netherlands and the Rhineland Horst Carl 


\title{
Foreword to the Series
}

\author{
Rafe Blaufarb, Alan Forrest and Karen Hagemann
}

The century from 1750 to 1850 was a seminal period of change, not just in Europe but across the globe. The political landscape was transformed by a series of revolutions fought in the name of liberty most notably in America and France, of course, but elsewhere, too: in Geneva and the Netherlands during the eighteenth century and across much of mainland Europe by 1848. Nor was such change confined to the European world. New ideas of freedom, equality and human rights were carried to the furthest outposts of empire, to Egypt, India and the Caribbean, which saw the creation in 1801 of the first black republic in Haiti, the former French colony of Saint-Domingue. And in the early part of the nineteenth century they continued to inspire anti-colonial and liberation movements throughout Central and Latin America.

If political and social institutions were transformed by revolution in these years, so, too, was warfare. During the quarter-century of the Revolutionary and Napoleonic Wars, in particular, Europe was faced with the prospect of 'total' war, on a scale unprecedented before the twentieth century. Military hardware, it is true, evolved only gradually, and battles were not necessarily any bloodier than they had been during the Seven Years War. But in other ways these can legitimately be described as the first modern wars, fought by mass armies mobilized by national and patriotic propaganda, leading to the displacement of millions of people throughout Europe and beyond, as soldiers, prisoners of war, civilians and refugees. For those who lived through the period these wars would be a formative experience that shaped the ambitions and the identities of a generation.

The aims of the series are necessarily ambitious. In its various volumes, whether single-authored monographs or themed collections, it seeks to extend the scope of more traditional historiography. It will study warfare during this formative century not just in Europe, but in the Americas, in colonial societies, and across the world. It will analyse the construction of identities and power relations by integrating the principal categories of difference, most notably class and religion, generation and gender, race and ethnicity. It will adopt a multi-faceted 
approach to the period, and turn to methods of political, cultural, social and military history, and of art history, in order to develop a challenging and multi-disciplinary analysis. Finally, it will examine elements of comparison and transfer and so tease out the complexities of regional, national and global history. 


\section{Acknowledgements}

This book is the result of a workshop hosted by the Anglo-German research group 'Nations, Borders, Identities: The Revolutionary and Napoleonic Wars in European Experiences and Memories' (NBI) and the German Historical Institute, London (GHI). The workshop held at the GHI in London on 24 and 25 February 2006 was organized by Karen Hagemann (University of North Carolina at Chapel Hill) and Ruth Leiserowitz (Berlin School for Comparative European History), in co-operation with the GHI. It built upon discussions held at previous NBI workshops, in November 2004 at the Military Research Centre, Potsdam, and in November 2005 at the European Academy, Berlin. At the London workshop seventeen participants from seven countries presented papers relating to the experiences and perceptions of soldiers and civilians in different European countries. For this volume the editors selected nine papers to be rewritten for publication, and invited two scholars to write new papers for the book on significant topics absent from the workshop. The Arts and Humanities Research Council, the GHI, and the German Research Foundation generously funded the workshop. The editors would like to thank all the participants in the workshop for their stimulating presentations and contributions to discussion, the authors for their willingness to co-operate so fully in the rewriting and editing of the essays, and the three foundations for making both the event and the resulting book possible.

Chapel Hill and York, Alan Forrest, Karen Hagemann and Jane Rendall 


\section{Notes on Contributors}

Katherine Aaslestad is an Associate Professor in the Department of History at the West Virginia University. Her main research interests are modern German and European history, especially political culture, the experience and memory of war, and gender. Recent publications include Place and Politics: Local Identity, Civic Culture, and German Nationalism in North Germany during the Revolutionary Era (Leiden, 2005); chapters in Patriotism, Cosmopolitanism, and National Culture: Public Culture in Hamburg, 1700-1933, ed. Peter Uwe Hohendahl (Amsterdam, 2003), and Gender in Transition: Breaks, and Continuities in German-Speaking Europe, 1750-1830, eds Marion Gray and Ulrike Gleixner (Michigan, 2006); and articles in Central European History and European History Quarterly. With Karen Hagemann, she was guest editor of a special issue of the journal Central European History 39: 4 (2006): 'New Perspectives on the Period of the Anti-Napoleonic Wars, 1806-1815'.

Horst Carl is Professor of Modern History at the Justus-Liebig University of Giessen. His research focuses on early modern Central European history, particularly military, social and cultural history. He was a member of the research group on 'Experiences of War', funded by the German Research Foundation and affiliated with the University of Tübingen, and is now working with the research group on 'Memory Cultures' at the University of Giessen. His own project is on 'Experiences of War and Religion in the Netherlands, Belgium and the Rhineland, 17921815'. His publications include Der Schwäbische Bund 1488-1534. Landfrieden und Genossenschaft im Übergang vom Spätmittelalter zur Reformation (The Swabian League 1488-1534) (Leinfelden, 2000); Die Erfahrung des Krieges. Erfahrungsgeschichtliche Perspektiven von der Französischen Revolution bis zum Zweiten Weltkrieg (The Experiences of War) (Paderborn, 2001), co-edited with Nicolas Buschmann; Kriegsniederlagen. Erfahrungen und Erinnerungen (Military Defeats. Experiences and Memories) (Berlin, 2004), co-edited with Hans-Henning Kortüm, Dieter Langewiesche and Friedrich Lenge.

John Cookson recently retired from the School of History at the University of Canterbury, New Zealand, and is Adjunct-Professor there. He continues to research in British (including Scottish and Irish) 
eighteenth- and nineteenth-century history. At present his main interest is in military pensioners after 1815, and in Scotland's military tradition. His recent publications include Southern Capital: Christchurch. Towards a City Biography 1850-2000, co-edited with Graeme Dunstall (Christchurch, 2000); 'The Edinburgh and Glasgow Duke of Wellington Statues: Early Nineteenth Century Unionist Nationalism As a Tory Project', Scottish Historical Review 78:1 (2004): 23-40; 'Service without Politics? Army, Militia and Volunteers during the American and French Revolutionary Wars', War in History 10:4 (2003): 381-397; The British Armed Nation, 1793-1815 (Oxford, 1997).

Jarosław Czubaty has been a Lecturer at the University of Warsaw since 1986. His main field of research is Polish history between 1788 and 1830, and in particular the Napoleonic era in Poland. His interests focus on the development of political mentalities and political ideas. His recent publications include Wodzowie i politycy. Generalicja polska 1806-1815 (Commanders and Politicians. Polish Generals 1806-1815) (Warsaw, 1994); Rosja i świat. Wyobraźnia polityczna elity władzy imperium rosyjskiego w poczatkach XIX w. (Russia and the World. The Political Imagination of the Elite of the Russian Empire at the Beginning of the 19th Century) (Warsaw, 1997); 'Progress and Violence in Political Reality: the Political Imagination of the Elite of the Russian Empire at the Turn of the XVIIIth century', in Progrès et violence au XVIIIe siècle (Progress and Violence in the 18th century), eds Valerie Cossy and Deidre Dawson (Paris, 2001); Zasada "dwóch sumien". Normy postępowania i granice kompromisu politycznego Polaków w sytuacjach wyboru (1795-1815) (The Rule of 'Two Consciences'. The Norms of Conduct and the Limits of Political Compromise for the Poles in Choice Situation 1795-1815) (Warsaw, 2005).

Alan Forrest is Professor of Modern History at the University of York. He works on modern French history, especially the period of the French Revolution and Empire, and on the history of modern warfare. He serves on the editorial boards of French History and War in History, and is a member of the advisory committee for Annales historiques de la Révolution Française. He currently directs the British project on 'Nations, Borders, Identities: The Revolutionary and Napoleonic Wars in European Experience', funded by the Arts and Humanities Research Council. His publications include The French Revolution and the Poor (New York, 1981); Conscripts and Deserters: The Army and French Society during the Revolution and Empire (Oxford, 1989); Soldiers of the French Revolution 
(Durham, 1990); Napoleon's Men: The Soldiers of the Revolution and Empire (London, 2002); Paris, the Provinces and the French Revolution (London, 2004); co-authored with Jean-Paul Bertaud and Annie Jourdan, Napoleon, le monde et les Anglais (Napoleon, the World and the English) (London, 2004). With Philip Dwyer, he recently edited a collection of essays for Palgrave on Napoleon and his Empire (London, 2007).

Karen Hagemann is James G. Kenan Distinguished Professor of History at the University of North Carolina at Chapel Hill. Her research focuses on the history of Germany and Europe from the eighteenth through twentieth centuries, and women's and gender history, in particular the history of welfare states, labour culture and women's movements, as well as the history of the nation, the military and war. She currently directs the British-German research project 'Nations, Borders, Identities: The Revolutionary and Napoleonic Wars in European Experience and Memory', funded by the Arts and Humanities Research Council and the German Research Foundation. Her most recent books include Gendered Nations: Nationalisms and Gender Order in the Long Nineteenth Century, co-edited with Ida Blom, Catherine Hall (Oxford, 2000); Home/Front: Military and Gender in 20th Century Germany, co-edited with Stefanie Schüler-Springorum (Oxford, 2002); 'Mannlicher Muth und Teutsche Ehre': Nation, Militär und Geschlecht zur Zeit der Antinapoleonischen Kriege Preußens (Manly Valour and German Honour: Nation, Military and Gender in Prussia during the Period of the AntiNapoleonic Wars) (Paderborn, 2002); Masculinities in Politics and War: Gendering Modern History, co-edited with Stefan Dudink and John Tosh (Manchester, 2004); Militärische Erinnerungskultur. Soldaten im Spiegel von Biographien, Memoiren and Selbstzeugnissen (Military Memory Culture: Soldiers in the Mirror of Autobiographical Documents), co-edited with Michael Epkenhans and Stig Förster (Paderborn, 2006).

David Hopkin is Fellow in Modern History at the Hertford College at the University of Oxford. His current research focuses on oral culture in nineteenth-century France (often with a military or maritime twist), and, in collaboration with Breton colleagues, a history of the British raids on Brittany in the Seven Years' War. Recent publications include Soldier and Peasant in French Popular Culture, 1766-1870 (Woodbridge: New York, 2002); 'Female Soldiers and the Battle of the Sexes in France: The Mobilisation of a Folk Motif', History Workshop Journal 56(2003): 78-104; 'Sieges, Seduction and Sacrifice in Revolutionary War: The "Virgins of Verdun", 1792', European History Quarterly 37: 4 (2007) 
(with Yann Lagadec and Stéphane Perréon), 'The Experience and Culture of War in the Eighteenth Century: The British Raids on the Breton Coast, 1758', French Historical Studies 31:2 (2008).

Johan Joor is honorary research fellow at the International Institute of Social History, Amsterdam. His research focuses on the history of the Napoleonic period in Holland. Recently he has worked on the Continental System and its consequences for Holland. His main publications include De Adelaar en het Lam. Onrust, opruiing en onwilligheid in Nederland ten tijde van het Koninkrijk Holland en de Inlijving bij het Franse Keizerrijk (1806-1813) (The Eagle and the Lamb: Unrest, Incitement, and Unwillingness in the Netherlands during the Kingdom of Holland and the Incorporation in the French Empire (1806-1813)) (Amsterdam, 2000); 'Les Pays-bas contre l'impérialisme napoléonien: les soulèvements anti-français entre 1806 et 1813' (The Netherlands against Napoleonic Imperialism: Anti-French Uprisings between 1806 and 1813), Annales historiques de la Révolution Française, 326 (2001): 161-171; 'De huid die niet mocht zweten. Het continentaal stelsel en de betekenis daarvan voor het Koninkrijk Holland' (The Skin that was Forbidden to Sweat. The Continental System and its Consequences for the Kingdom of Holland.), De Negentiende Eeuw 30 (2006): 242-254.

Catriona Kennedy is Research Fellow at the Centre for Eighteenth Century Studies at the University of York, working with the research project 'Nations, Borders, Identities: The Revolutionary and Napoleonic Wars in European Experience', funded by the Arts and Humanities Research Council. Her research interests include the Revolutionary and Napoleonic wars and the history of Irish nationalism, with a particular focus on the relationship between gender, politics and national identity. She has published "Womanish Epistles": Martha McTier, female epistolarity and late eighteenth-century Irish radicalism', Women's History Review 13:1 (2004): 649-667; and “"A Gallant Nation": Chivalric Masculinity and Irish Nationalism in the 1790s', in Public Men. Masculinity and Politics in Modern Britain ed. Matthew McCormack (Basingstoke, 2007). She is currently writing a monograph on War, Experience and Identities: Britain and Ireland, 1793-1815.

Patricia Lin was Assistant Professor at the History Department in the University of San Francisco from 1999 to 2001 and Lecturer in the History Department and on the International and Area Studies Teaching 
Program at the University of California, Berkeley from 1998-1999, and 2004-2005. Her main research interest is the impact of war on children, families and states. Her publications include 'Citizenship, Military Families and the Creation of a New Definition of "Deserving Poor" in Britain, 1793-1815', Social Politics 7:1 (2000): 5-46; and 'National Identity and Social Mobility: Class, Empire and the British Government Overseas Evacuation of Children during the Second World War', Twentieth Century British History 7:3 (1996): 310-344. She is currently completing a manuscript entitled Family, War and the British State, 1793-1815 and is Senior Writer and Analyst at the Center for Educational Partnerships, University of California, Berkeley.

Kevin Linch is Teaching Fellow at the School of History at the University of Leeds. His main field of research is Britain's military mobilization during the French Revolutionary and Napoleonic Wars, in relation to both the British Army and the auxiliary and part-time forces. He teaches on British society in the 1790 s and on warfare, state, and society in Britain and France in the long eighteenth century. His recent publications include " "This Exposed Maritime County": East Sussex and the Preparations for Invasion, 1803-04', The Trafalgar Chronicle 16 (2006): 50-61; 'A Geography of Loyalism? The Local Military Forces of the West Riding of Yorkshire, 1794-1814', War \& Society 19 (2001): 1-21; Recruiting the British Army 1807-1815 (Leeds, 2001).

Natalie Petiteau is Professor of History at the University of Avignon. Since September 2000 she is editor of the calendar website of social science www.revues.org/calenda. Her main research interests are the history of the nineteenth century and especially the Napoleonic period. Her recent publications include Elites et nobilités: la noblesse d'empire au XIX siècle (The Nobility of the Empire during the 19th century) (Paris, 1997); Napoléon de la mythologie à l'histoire (Napoleon from Mythology to History) (Paris, 1999); Lendemains d'Empire: Les soldats de Napoléon dans la France du XIXième siècle (The Aftermath of Empire: The Soldiers of Napoleon in Nineteenth-century France) (Paris, 2003); Les Français et l'Empire 1799-1815 (The French and Empire) (Paris, 2008).

Jane Rendall is Honorary Fellow in the History Department and the Centre for Eighteenth Century Studies at the University of York. She is interested in eighteenth- and nineteenth-century British and comparative women's history, and particularly in Scottish women's history. She is a member of the board of the project 'Nations, Borders, Identities: The 
Revolutionary and Napoleonic Wars in European Experience', funded by the Arts and Humanities Research Council. Her publications include The Origins of Modern Feminism (Basingstoke, 1985); Women in an Industrializing Society: England 1750-1880 (Oxford, 1990); co-authored with Catherine Hall and Keith McClelland, Defining the Victorian Nation (Cambridge, 2000); co-edited with Mark Hallett, Eighteenth-Century York: Culture, Space and Society (York, 2003). 